\title{
Globalization and Gender Inequality- An Agricultural Perspective
}

\author{
Sanjay B. Salunke \\ Associate Professor Department of Sociology Dr. Babasaheb Ambedkar Marathwada University, Aurangabad \\ Pin - 131001 (Maharashtra State) India.
}

\begin{abstract}
Most of the population in India is dependent on agriculture and agro-based industries. Farmer is at the center of the occupation. Hence, it is important to comprehend economic and social situation of the female farmers who are at the centre. Therefore, the research entitled Globalization and Gender Inequality: with special reference to agriculture is undertaken. There are rapid changes observed in the social structure in the process of globalization. There are new laws, thoughts, economy, education system, values, institution; concepts etc. all go through changes in the process of globalization in context of research. Of the 722 villages from Osmanabad district, 360 respondents were selected by purposive sampling method. The research analyses post 1991 policies, globalization, modern technology, theoretical base of globalization, Indian agriculture system. Female agricultural workers and globalization and other aspects have been discussed. In short, women empowerment in economic terms and decrease in female dependence on male has been the objective of the research.
\end{abstract}

[Key Words: Development, Gender, Farmer, Labour, Agriculture.]

\section{Introduction}

Economic developments of India are divided into pre-Independence and post Independence stages. First stage is said to be from 1757 to 1857 while second stage is from 1947 to 1991. The second stage of 1991 is changing stage in terms of economic revolution. (Murty Narayan 2007:45) World economy is divided chiefly into capitalist, socialist and complex types India has accepted complex economy for its development complex economy has extended industrialization as its foundation. Hence, rural industries, national industries and private industries all are given due weightage in the policy formation. India accepted complex economy because private sectors were not ready to venture into basic services of the people. So, government thought from socialist point of view and accepted complex economic nature. In the context of Indian society, the role of family is vital in social control. Most of the people retain their social status by using social and cultural values of the society because; the family background of the person determines his status in the society. Many sociologists (Durkheim1950, Sorokin 1927, Ghurye 1961, Das 1968, Brown 1952 and Kapadia 1956:111-126) are of the view that person's sex, age, caste, religion, family, education, marital status and residence are the important factors of social system that affects person's behavior also. India is now passing through a conflict before globalization and social impact of economic reforms. Most of the people in the society are away from the stream of development. It has caused disparity among Indian society such situation has given rise to poor and rich classes in the society. Recently, these classes are known as loser and winners respectively. Globalized businessmen, technocrats, educationalist, and Industrialist are winners while uneducated labourers, tribal communities, women labourers are losers. It has given rise to new stratification in the society. This has also brought a new aspect to the study of sociology in the globalization perspective since 1991 .

The United Nations conferences held during the decade of the 1990s provided the opportunity for women to take their demands one step further, mainstreaming their concerns into the UN human rights and human development agendas. Beginning with the 1992 United Nations Conference on Environment and Development (UNCED), in Rio de Janeiro, Brazil, women from around the globe came together to strategize and to gain formal recognition of their crucial role in achieving a new kind of development that is socially, economically and environment all sustainable. At subsequent conferences women won significant government commitments to protect and advance women's human rights, reproductive health and rights, poverty and social development, and a broad platform of political, social and economic action (Frankson 2002).

Last two decades in India has seen the transition in agriculture of India. We have seen that the number of farmers (who toil their land) and landless labourers has decreased. The population which depends upon agriculture has also decreased. At the same time the number of farmers and agricultural labourers has increased. But as per census 2001 the number of population associated with agriculture has decreased after 1991.Nilkanth Rath says, "Only those farmers and labourers who really have interest in agriculture could survive in agriculture sector in future" He further says that the number of agricultural labourers in total labourer has decreased. Yet 
number of laborers has increased during the period 1991-2001 in which number of women laboures has increase, if we see the background of the globalization to David Harvey (2000), globalization per se is not new and can be dated back at least to 1492 with the internationalization of trade and commerce. This current phase, however, is significant for the profound reorganization of geography, where prior configurations of borders and boundaries are rapidly reshaped effecting change in the politics of gender, class, and place. These changes have caused some to speculate on the demise of prior configurations of boundaries such as the nation-state (Appadurai 1996); while others see this more as a "nexus" between global and local scales (Wilson and Dissanayake 1996).

Modern technology determines the role of women in agriculture. Since, many modern technologies have taken the job of women. Hence, women's role is vanished. Modern technology is taught to males only by agricultural officers who are prejudiced. Therefore, women do not find any space to stand in. Modern technology has left women and landless labourers away from the campus of the sector. At the same time women are also expelled from market and arts sector. The product made by women does not get market and expected return; hence, women have turned into landless agricultural labourer. However, according to Ramgopal Singh, "Globalization has made the thinking of women broader and modern" The speed dynamism of women have increased which involves political participation of women. Women are now interested in power and wealth. Globalization has given market to the produce of unorganized women labours. It has also increased opportunities to them. It means women are now empowered in the villages and they are now not dependent on men such psychological thinking is observed. Alwins has studied the gender inequality in USA. He says that women need to be given knowledge of modern technology in order to improve agriculture. But, in the process of globalization women are dropped from the training of modern technology and men are getting at the centre. Consequently, women spend most of their time in taking care of family (Leeder 2004:131). Such condition is observed in both developed and developing countries. Rural farmers and agricultural women labourers are some extent getting released from family, economic, social and cultural restrictions and become the source of economic earning in rural families. However, this economic earning is spent not by them but by the others. Therefore, Mohammad Yunus established Self Help Group at Chittagong in 1983 in Bangladesh. Self Help Groups were started in India in 1991. There were more than 250 self help groups in India. The movement has accelerated since 1998 which has freed people from the clutches of private moneylenders. Now days Banks and co-operative bodies are providing assistance to SHG. It is because if women are empowered, then they can get respect in society. Besides, it is backward to keep women undeveloped in the process of globalization. Hence, women self help groups are working collectively.

Most female workers in agriculture perform housework or are employed in the informal sector

(Bacchus and Foerster 2005).The share of women population in agriculture is 50\% and the percentage of women in agricultural labour is $60 \%$. At the outset, the share of women in agriculture has increased so women farmer empowerment scheme has started; this scheme has no doubt affected the traditional thinking.

P. Maraki Kumari, K. Mahendra Kumar and B.S. Rao (2011:168) Discussed about the opportunities and positive and negative impact of globalization upon women. They said that due to fast process of globalization there has emerged a new system which is based on information and communication technology. But, women have not been trained properly and their presentation is not equal. Hence, there are number of challenges before them. The research also discussed about role of women in agricultural produce, and ownership rights of women in positive manner. It has also discussed about agricultural export, contract farming, world trade organization, TRIPS, women's right about food in the context of globalization. In this gender perspective is discussed. It also focuses on industrial ownership, special economic zone and problem of displacement.

\subsection{Theoretical Basis of Globalization}

The process of globalization has expanded and marketed expansion of industry, mechanical growth, transportation and culture in many countries. This has resulted into minimization of gap between persons of different countries. Ex. Tribes from trobriand Island of Australia have accepted the process of modernization. It does not mean that only tribals have been affected by globalization there are other sections as well like politics, governance etc. It is necessary to elaborate the theory of globalization, dependence theory and modernization here; researcher has taken the basis of theory of globalization.

\subsection{Concepts used in the Research}

Anthony Giddens says about globalization when he explains globalization from sociological perspective, that globalization means interdependence of people, region and country in social and economic terms in the world. According to Yogendra Singh (2000:41) globalization is such a process in which dynamic aspects of life such as banking and finance, business and foreign relations and lifestyle have been changed revolutionarily in due time. Webster's new world dictionary of the American language says "restructuring of 
internal parts and management of small aspects of social structuring means agricultural structure. In the Stantons book (1991:2) Quinton, Penn and Boehm says "Area of agriculture, ownership of resources and capital and technological need and their fulfillment is known as agri-structure. Famous philosopher Beyfried says, "Child becomes male and female and it is known as gender inequality" In short, male and female are made in the process of socialization.

There are structures in any part of society. Agriculture is not exception to that. There are small, medium, large Landless labours are the structures. This structuration is subject to place, time and situation. Water is an important resource necessary for agriculture. As per NABARD land is divided into irrigated and Non-irrigated types and accordingly the farmers are classified as small, medium and large etc. keeping this factor in mind researcher has classified the farmers. Those farmers owning land unto 5 acres are small farmers, more than 5 acres and less than 10 acre are medium farmers and those who have more than 10 acres of land are big farmers. It is difficult to define those landless labourers. Yet, those who work in others farm whole the year and survive on the income they get in the form of wages are called landless labourers.

\subsection{Research Methodology:}

\section{Objectives:}

1. To study gender inequality in agriculture structure.

\section{Hypothesis:}

1. Gender inequality in ownership of land in agric structure still exists even after of the process of globalization.

Keeping in mind the objectives, hypothesis and data, there are only 06 talukas selected out of 722 villages from Osmanabad district on sample basis. There are 03 villages each from 6 talukas. So, there are 18 villages in all. There are 05 farmers each from large, medium and small landless labour categories. It means there are 60 variable from each taluka. Here, 360 respondents (landless labourers and farmers) are selected for the data collection. Purposive sampling method of non-probability sampling method (Bhandarkar and Wilkinson 2009:16) is selected. The primary sources for the research are interview schedule. While government documents, census reports, agricultural surveys, survey of autonomous institutes, published and non published reference books, daily news papers, periodicals magazine and internet data are secondary sources.

\subsection{Importance of Research}

There has been lack of research in rural agriculture structures. It is due to the disinterest. Those neglected factors have been centre of problems. It needs to be focused. In rural area, where most of the farmers live women are working in farm while non-agriculture works are dominated by males. It means, development should be researched with socio-cultural perspective because social disparity has been feature of disparity in India. This disparity is giving rise to a new colonial nature to the process of globalization. In this context the research is important.

\subsection{Gender, Marital status and Age group:}

Both male and female get psychological stability with marriage. The institution of marriage has been playing an important role in sustaining family as an institution. Because it gives way to a new upcoming socially accepted family. The age of marriage is also affected by industrialization and Urbanization. At the same time person gets his/her responsibilities with the age. Table 1, describes gender, age and marital status of respondents.

Table 1

Gender, Marital status and Age group

\begin{tabular}{|c|c|c|c|c|c|c|c|c|c|}
\hline \multirow[t]{2}{*}{ Gender } & \multirow{2}{*}{$\begin{array}{c}\text { Marital } \\
\text { status }\end{array}$} & \multicolumn{6}{|c|}{ Age group } & \multirow[t]{2}{*}{ Total } & \multirow[t]{2}{*}{ Percentage } \\
\hline & & $\begin{array}{c}\text { Up to } 25 \\
\text { years }\end{array}$ & $\begin{array}{c}26 \text { to } 35 \\
\text { years }\end{array}$ & $\begin{array}{c}36 \text { to } 45 \\
\text { years }\end{array}$ & $\begin{array}{c}46 \text { to } 55 \\
\text { years }\end{array}$ & $\begin{array}{c}56 \text { to } 65 \\
\text { years }\end{array}$ & $\begin{array}{l}66 \text { and } \\
\text { above }\end{array}$ & & \\
\hline \multirow[t]{5}{*}{ 1.Male } & Unmarried & 2 & 5 & -- & -- & 1 & -- & 8 & 2.22 \\
\hline & Married & 10 & 77 & 69 & 68 & 67 & 41 & 332 & 92.22 \\
\hline & Widower & -- & -- & -- & 1 & 2 & 4 & 7 & 1.95 \\
\hline & Divorced & -- & 1 & 2 & -- & -- & -- & 3 & 0.83 \\
\hline & Total & 12 & 83 & 71 & 69 & 70 & 45 & 350 & 97.22 \\
\hline \multirow[t]{3}{*}{ 2.Female } & Married & -- & -- & 1 & 3 & -- & -- & 4 & 1.11 \\
\hline & Widow & -- & -- & 1 & 1 & 3 & 1 & 6 & 1.67 \\
\hline & Total & -- & -- & 2 & 4 & 3 & 1 & 10 & 2.78 \\
\hline Total & Unmarried & 2 & 5 & -- & -- & 1 & -- & 8 & 2.22 \\
\hline
\end{tabular}


Globalization and Gender Inequality- An Agricultural Perspective

\begin{tabular}{|l|l|c|c|c|c|c|c|c|c|}
\hline \multirow{7}{*}{} & Married & 10 & 77 & 70 & 71 & 67 & 41 & 336 & 93.33 \\
\cline { 2 - 10 } & Widower & -- & -- & -- & 1 & 2 & 4 & 7 & 1.95 \\
\cline { 2 - 10 } & Widow & -- & -- & 1 & 1 & 3 & 1 & 6 & 1.67 \\
\cline { 2 - 10 } & Divorced & -- & 1 & 2 & -- & -- & -- & 3 & 0.83 \\
\cline { 2 - 10 } & Total & 12 & 83 & 73 & 73 & 73 & 46 & 360 & 100 \\
\cline { 2 - 10 } & Percentage & 3.33 & 23.05 & 20.28 & 20.28 & 20.28 & 12.78 & 100 & \\
\hline
\end{tabular}

According to table 1 there are 229 respondents from 26-55 age groups and their share is 63.31. From population point of view this group is considered dynamic working. The number of widower is lesser than those of widows. Because most of widowers get remarried, in the context of globalization now male also has to go for divorce. Such is the opinion of 03 male respondents. There were no divorced women found. In case of widows, their children help than in handling the responsibility of family. Most of cases women run the families.

Table No.2

Landless laborers, their age group, sex and wages

\begin{tabular}{|c|c|c|c|c|c|c|c|c|}
\hline \multirow{2}{*}{ Gender } & \multirow{2}{*}{ Age Group } & \multicolumn{5}{|c|}{ Laborer wage in Rs. } & \multirow{2}{*}{ Total } & \multirow{2}{*}{ Percentage } \\
\hline & & 100 & 101 to 150 & 151 to 200 & 201 to 250 & $\begin{array}{c}251 \text { and } \\
\text { above }\end{array}$ & & \\
\hline \multirow{7}{*}{ Male } & Up to25 years & 1 & 2 & -- & 1 & -- & 4 & 4.44 \\
\hline & 26 to 35 years & 4 & 12 & 1 & 1 & 1 & 19 & 21.11 \\
\hline & 36 to 45 years & 2 & 8 & 4 & -- & -- & 14 & 15.56 \\
\hline & 46 to 55 years & 6 & 9 & 4 & -- & 1 & 20 & 22.22 \\
\hline & 56 to 65 years & 2 & 11 & 2 & -- & -- & 15 & 16.67 \\
\hline & 66 years and above & 7 & 4 & 1 & -- & -- & 12 & 13.33 \\
\hline & Total & 22 & 46 & 12 & 2 & 2 & 84 & 93.33 \\
\hline \multirow{5}{*}{ Female } & 36 to 45 years & --- & 1 & -- & -- & -- & 1 & 1.11 \\
\hline & 46 to 55 years & -- & 2 & -- & -- & -- & 2 & 2.22 \\
\hline & 56 to 65 years & 1 & 1 & -- & -- & -- & 2 & 2.22 \\
\hline & 66 years and above & 1 & -- & -- & -- & -- & 1 & 1.11 \\
\hline & Total & 2 & 4 & -- & -- & -- & 6 & 6.67 \\
\hline \multirow{8}{*}{ Total } & Up to 25 years & 1 & 2 & -- & 1 & -- & 4 & 4.44 \\
\hline & 26 to 35 years & 4 & 12 & 1 & 1 & 1 & 19 & 21.11 \\
\hline & 36 to 45 years & 2 & 9 & 4 & -- & -- & 15 & 16.67 \\
\hline & 46 to 55 years & 6 & 11 & 4 & -- & 1 & 22 & 24.44 \\
\hline & 56 to 65 years & 3 & 12 & 2 & -- & -- & 17 & 18.90 \\
\hline & 66 years and above & 8 & 4 & 1 & -- & -- & 13 & 14.44 \\
\hline & Total & 24 & 50 & 12 & 2 & 2 & 90 & 100 \\
\hline & Percentage & 26.7 & 55.6 & 13.3 & 2.2 & 2.2 & 100 & \\
\hline
\end{tabular}

According to table 2 Researcher tried to find out the correlation between age and wages. There are $55.6 \%$ respondents who get their wages between 101 to 150 in which the age group is 26 to 65 years. According to $26.7 \%$ respondents the wage for them is Rs. 100. These are respondents whose age is above 56 years. It makes clear that there is correlation between age and wage.

It makes clear that the tendency of giving priority to make workers than female workers is vanishing day by day, while the work is given to those who are from age group 14-59 years. Thus, it makes clear those females are also doing any work as efficiently as male. This is even found in agriculture sector also.

Table No. 3

Ownership of land and gender

\begin{tabular}{|c|c|c|c|c|c|}
\hline \multirow{2}{*}{ Sr.no. } & \multirow{2}{*}{ Land Holding (in Acres ) } & \multicolumn{2}{|c|}{ Gender } & \multirow{2}{*}{ Total } & \multirow{2}{*}{ Percentage } \\
\hline & & Male & Female & & \\
\hline 1. & Landless Labour & 84 & 6 & 90 & 25.0 \\
\hline 2. & 0 to 5 & 49 & 1 & 50 & 18.5 \\
\hline 3. & 5.1 to 10 & 39 & 1 & 40 & 14.8 \\
\hline 4. & 10.1 to 15 & 65 & 1 & 66 & 24.4 \\
\hline 5. & 15.1 to 20 & 24 & -- & 24 & 8.9 \\
\hline
\end{tabular}


Globalization and Gender Inequality- An Agricultural Perspective

\begin{tabular}{|c|l|c|c|c|c|}
\hline 6. & 20.1 to 25 & 38 & -- & 38 & 14.1 \\
\hline 7. & 25.1 to 30 & 27 & -- & 27 & 10.0 \\
\hline 8. & 30.1 to 35 & 5 & -- & 5 & 1.9 \\
\hline 9. & 35.1 to 40 & 5 & -- & 5 & 1.9 \\
\hline 10. & 50.1 to 55 & 8 & -- & 8 & 3.0 \\
\hline 11. & 60.1 to 65 & 4 & 1 & 5 & 1.9 \\
\hline 12. & 95.1 to 100 & 2 & -- & 2 & 0.7 \\
\hline \multicolumn{2}{|c|}{ Total } & 350 & 10 & 360 & 100 \\
\hline
\end{tabular}

According to table 3 there are ten women respondents of the total respondents. Because six women are widows and of the remaining respondents husbands of two women have merited, while two women have to take care of entire family. It shows that even today also in most of the cases the responsibility of family and ownership of land are in the hands of male.

Table No.4

Male and Female agriculture laboures and their wages in percentagewise

\begin{tabular}{|c|c|c|c|c|c|c|c|c|}
\hline \multirow{2}{*}{$\begin{array}{l}\text { Workers } \\
\text { on weekly } \\
\text { wages }\end{array}$} & \multicolumn{2}{|c|}{$\begin{array}{l}\text { Position male workers } \\
\text { before (1991) }\end{array}$} & \multicolumn{2}{|c|}{$\begin{array}{l}\text { Position of male workers } \\
\text { (2013) }\end{array}$} & \multicolumn{2}{|c|}{$\begin{array}{l}\text { Position female workers } \\
\text { before(1991) }\end{array}$} & \multicolumn{2}{|c|}{$\begin{array}{l}\text { Position of female } \\
\text { workers (2013) }\end{array}$} \\
\hline & Respondents & Percentage & Respondents & Percentage & Respondents & Percentage & Respondents & Percentage \\
\hline 1 & 16 & 5.9 & 19 & 7.0 & 35 & 13.0 & 19 & 7.0 \\
\hline 2 & 21 & 7.8 & 12 & 4.4 & 38 & 14.1 & 24 & 8.9 \\
\hline 3 & 7 & 2.6 & 11 & 4.1 & 31 & 11.5 & 33 & 12.2 \\
\hline 4 & 7 & 2.6 & 9 & 3.3 & 21 & 7.8 & 21 & 7.8 \\
\hline 5 & 3 & 1.1 & 2 & 0.7 & 8 & 3.0 & 19 & 7.0 \\
\hline 6 & 1 & 0.4 & 6 & 2.2 & 6 & 2.2 & 16 & 5.9 \\
\hline 7 & 2 & 0.8 & 3 & 1.1 & 7 & 2.6 & 19 & 7.0 \\
\hline 8 & -- & $\begin{array}{l}-- \\
\end{array}$ & - & -- & 6 & 2.2 & 5 & 1.9 \\
\hline 9 & -- & -- & -- & -- & 1 & 0.4 & 8 & 3.0 \\
\hline 10 & -- & -- & -- & -- & 1 & 0.4 & 14 & 5.2 \\
\hline 11 & -- & -- & -- & -- & 2 & 0.7 & 5 & 1.9 \\
\hline 12 & -- & -- & -- & -- & 4 & 1.5 & 3 & 1.1 \\
\hline 13 & -- & -- & -- & -- & 1 & 0.4 & 2 & 0.7 \\
\hline 20 & -- & -- & -- & -- & -- & -- & 6 & 2.2 \\
\hline $\begin{array}{c}\text { Workers not } \\
\text { on weekly } \\
\text { wages }\end{array}$ & 213 & 78.9 & 208 & 77.0 & 109 & 40.4 & 76 & 28.1 \\
\hline Total & 270 & 100 & 270 & 100 & 270 & 100 & 270 & 100 \\
\hline
\end{tabular}

According to table 4 above table indicates that the number of labourers who work on weekly payment is same today as it was before 1991 . There are $7.8 \%$ respondents who employed labours on weekly payment basis before 1991 and $4.4 \%$ respondents have employed the labourers on weekly payment basis today but with remaining respondents. There is rise in the number of labourers who work on weekly basis it is because these farmers now cultivate cash crops like sugarcane, cotton and banana. Such crops require more labourers and these labourers are male. There is decrease in the labourers who work not on weekly wages. As per the table it is shown that male labourers in 1991 were 78.9 whereas in 2013 it is 77.07. There is also decrease in workers as per 1991 data there were 40.4 female workers who were working not on weekly wages, but it is 28.1 in 2013 . It shows the globalization process has affected labourers.

In terms of female workers who work on weekly payment. It is seen that there are $4.26 \%$ respondents who employed women before 1991 and 5.14\% respondents have employed women now. Before 1991, there were very less women employed on weekly basis but now at present it is rising up to $5.2 \%, 1.1 \%, 0.7 \%$ and $2.2 \%$ respectively for $10,11,12,13$ and 20 workers. It shows that the number of women who are employed is greater than that of those before 1991 .

After studying the table we come to conclusion that marginal land owners do not get sufficient income from their land hence they work as labourers. There are more women than men among such workers. The reason behind this is those males migrate to cities for doing non-agricultural works while female work in the farm and stay in villages. Consequently, there is rise in matriarchal families in villages. 


\subsection{Conclusions and Findings:}

1. Only $2.8 \%$ (10) respondents are women it means today in most of the villages land and families are dominated by males.

2. Creativity is associated with women and agriculture was invented by women yet in the process of globalization women do not enjoy equal rights in terms of land and property.

3. Male preferred attitude for work is fading now days and those both male and female from working age group (14-59) are preferred now. It is now accepted that women can do the works that are done by men. Such kind of thought is positive aspect of process of globalization.

4. In the 1991 shows that female laborers is $59.62 \%$ and in 2013 it is $71.85 \%$ it shows that in the process of globalization there is rise in the number of women workers and decrease in male workers in farm.

5. There is rise in the number of marginal workers during 1991 to 2001 in which more number of female is seen.

6. Women are unaware of technology. It causes women stay away from the modern agricultural works. They lead their life outside.

7. The produce made by women does not get attractive price in the market. Hence, those emerging landless land laborers are from women of poor families.

8. The wealth achieved from agriculture is snatched by industrialization and globalization. Consequently, the system which exploits women has become stronger.

9. More the speed of privatization of health facilities in rural area more the superstitions women.

\section{References:}

[1]. Appadurai, Arjun. 1996. Modernity at Large: Cultural Dimensions of Globalization. Minneapolis: University of Minnesota Press

[2]. Bhandakar, P.L. \& Wilkinson T.S.2009. Methodology and Techniques of social Research. Mumbai: Himalaya Publishing House

[3]. Das, J.P. 1968. Authority, Power and Family Relationship in to Primitive Tribes of Udisa. The Eastern Anthropologist, Vol. 16, No. 3.

[4]. Durkheim, Emile. 1950. The Rules and Sociological Method. Elinaya: The Free Press of Glenco

[5]. Elaince, Leeder. 2004. The Family in Global Perspective: A Gendered Journey, New Delhi: Sage Publication.

[6]. Ghurye, G.S. 1961.Caste, Class and Occupation. Bombay: Popular Book Depot

[7]. Harvey, David. 2000. Spaces of Hope. Berkeley: University of California Press

[8]. http://ageconsearch.umn.edu/bitstream/121378/2/Cornell\%20SP\%2091-06.pdf.7/5/2013

[9]. http://www.fanancialexpress.com.news/adopt/nabard. 5 Nov. 2012.

[10]. Joan Ross Frankson (edit.) 2002. Women Challenging Globalization: A gender perspective on the United Nations International Conference on Financing for Development, March 18-22, Monterrey, Mexico

[11]. Kapadia, K.M. 1956. Rural Family Pattern's: A Study in Urban-Rural Relation. Sociological Bulletin Vol.-5.

[12]. Murty Narayan 2007.150 Years of Economic Development, Yojna, No.01Vol. 35.

[13]. Nazreen Bacchus, Dr Amy Foerster. 2005. The Effects of Globalization on Women in Developing Nations, Pace University, http://digitalcommons.pace.edu/honorscollege theses/2

[14]. P. Mercy Kumari, K. Mahendra Kumar and S.B. Rao. 2011. "Globalization and the Changing Role of Women in Agriculture," In Mohd. Iqbal Ali and G. Bhoskar (ed.) WTO, Globalization and Indian Agriculture, New Delhi: New Century Publication.

[15]. Radcliffe, Brown, A.R. 1952. Structure and Function in Primitive Sociology, New York: Macmillan Company.

[16]. Singh, Yogendra. 2000. Cultural Change in India: Identity and Globalization, New Delhi, Rawat Publication.

[17]. Sorokin, P.A. 1927. Social and Cultural Mobility. Elinaya: The Free Press Glenco

[18]. Stanton, B. F.1991. Farm Structure: Concept and Definition, New York: Department of Agricultural Economies sCornell University Agricultural Experiment Station.

[19]. Wilson, Rob, and Wimal Dissanayake, edit. 1996. Global/Local: Cultural Production and the Transnational Imaginary. Durham, N.C., and London: Duke University Press 